\title{
雜報
}

$\odot$ 人 事

鐵道輏 山 口 龍 契

年俸六百六拾圆下渴

鐵道㹂山口龍 契

願二依リ本職 $习$ 急 $ス$

敘正比位

(ス)ニ十ス日)

從七位大田原一禬

$(A H+$ 五B)

岡山醫科大學助票授 清 水勝 本偆十級侇下睗

(九月十ス日)

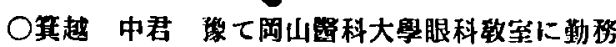

し居られし同君は先般岡山槽兒島郡日比町:并造

蛣所病院眼科部長に就任せられたり

○中富和夫君 は今般德島棌板野郡北島村東那人

造瀻維株式曾社㗨局に勤狢せられたり

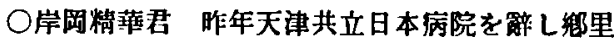

に於て静荃中なりしが今般八幡市清田町 3 丁目に

於て開業せられたり

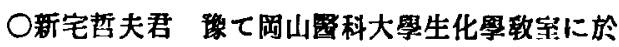
て研究中なりし同君は過般同票空を解し岡山市豐 成に於て開業せられたり

\section{$\odot$ 里位授與}

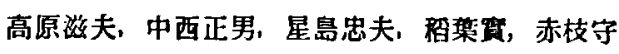
一，平井出正三の 6 君は称 て岡山㗨科大學に諭文 を提出し學位を請求し居られしが高原，中西，星 島の 3 君は本年 7 月 6 日，䄸葉，赤枝，本井出の 3 君は本年 7 月 20 日の敏授曾を通過し前者は本 月 4 日後者は本月 21 日敦れ。圈學博士の等位を 授興せられたり其の主論文及び考論文は㰠の如 L
高原㴚夫君

主論 文

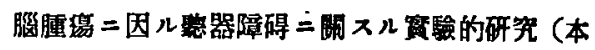

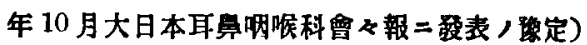
考諭文

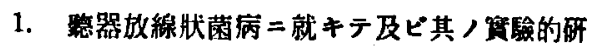

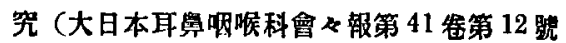
二砬表セリ)

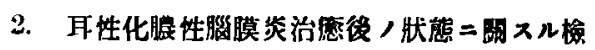
查成縝二就キテ（東京醫事新誌第 2907 咙二 霞表七り)

3. 結核性碩部淋巴腺桨二於ヶル口蓋扁桃腺揞

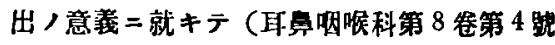
二覆表せり)

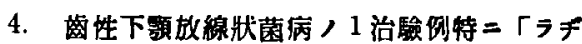
ウム」針刺入原法ノ效果 =就キテ（耳鼻咽啹 科第 8 卷第 7 躆二表表セり)

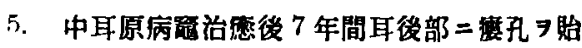

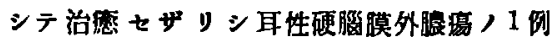

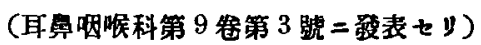

\section{中西 正男君}

主諭 文

實䮦家鬼徽毒，研究

其 1. 賽驗的家鬼徽毒二於ヶル伹清「リポイド

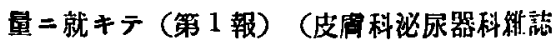
第 40 管 3 䟤二筑表セり)

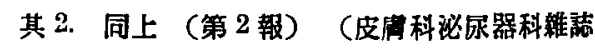
第 40 卷第 3 躆二幖表セり)

考論文

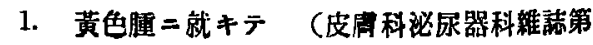


33 第 3 㩆二表七表七)

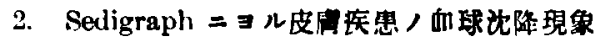

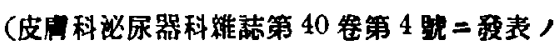
㨋定)

3. 尿管結石二就キテ（本誌第 43 年第 6 踋 二嘼表セり)

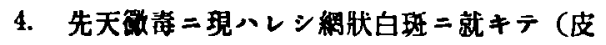

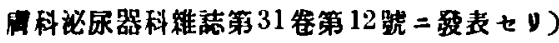

5. 頼宦官定二就キテ（本誌第 48 年第 9 躆 酸表七り)

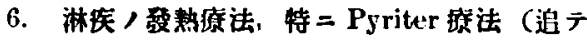
本誌二政表，定）

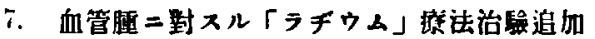
特二漆面「ラヂウム」)使用二就テ（本會雃 誌第 43 年第 2 跟上表七り)

星島忠夫君

主諨文

「テタニー」ト㙞计酸作用トノ關係二就キテ

其 1. 甲狀及ビ副甲状腺摘出犬ノ血中及ビ尿中 石灰量二及ボス脱计酸，作用卜其「ホルモン」 作用二就キテ（昭和 8 年 1 月外字生化學雜誌

二碚表セy)

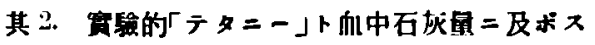

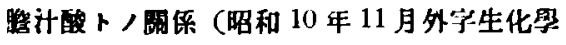
乘誌二覆セり)

\section{考論文}

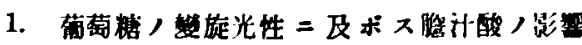

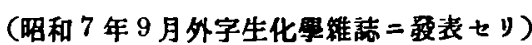

2. 血中無機及ビ有機撛䣬拿二及ボス「ヒョー

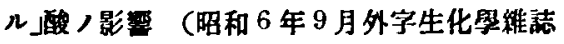
二表表七り)

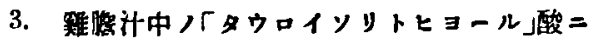
就キテ（高田, 浦诚, 蹗谷共著）（昭和!年 10 月外字生化學雜誌 $=$ 表表七り)
4. 蝮唾液中ノ醉菜二就キテ（高田，浦城，跸

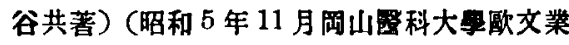
府二發表セリ)

5. 扁桃腺摘出後重篤ナル合併定 $\exists$ 來セル2们

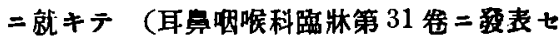
v)

\section{玿葉葢君}

圭論 文

售计酸，血腹凝固二對スル作用二就テ

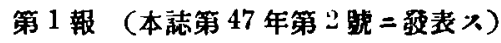

第 2 報 交感证二副交感神經卜，關係（本誌 第 47 年第 7 踾二表七り)

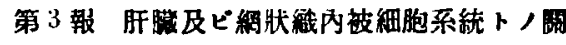

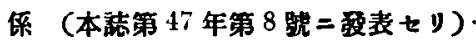

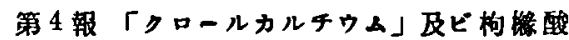
ナトリゥム」萑酸「ナトソウム」トノ閶係 （本誌第 47 年第 9 躆二数表七リ）

基考論交

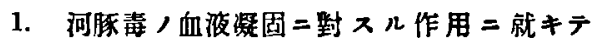
（本誌第 47 年第 12 躆二磉表七り）

2.「パラオキシベンチールク゚アニヂン」ノ血液 准固催進二及ボス「カルチウム」ノ影整二就キ

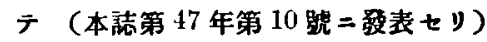

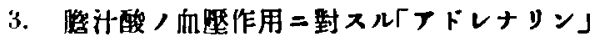

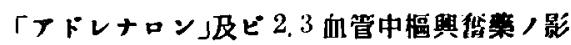
帮二就キテ（本綕第 48 年第 1 躆二表セり）

4. 孚酸，血液碾固二及ボ不影辢二就キテ（本 誌第 47 年第 12 號二踆表セり)

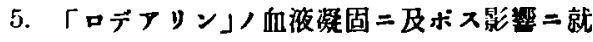
キテ（日本慈物悬維誌第 21 第 3 號二表表 セり)

6.「ハルミン」ノ血液凝固二及ポス作用二就キ

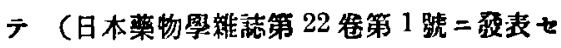
ע) 


$$
\text { 赤枝守一君 }
$$

主諭文

膀脂ニョル抗原，吸收立二局所反留二就キテ

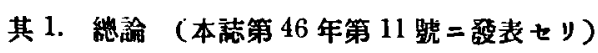

其 2. 血球 $=3$ 几腤肶免波（本誌第 46 年第 12 躆二器表セり)

其 3. 血清 $=3$ 几膀肶要疫 （本誌第 47 年第 9 號二僄セり)

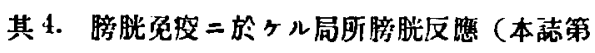
47 年第 10 號二覀表セり)

\section{考論文}

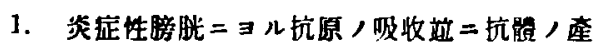
生（本誌第 48 年第 3 跟二發表セリ）

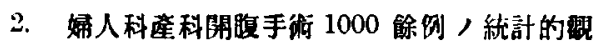
。祭（徒第 47 年第 1 踶二表表七り）

3. 娃娠各月二於ヶル子宮底，高廿二關ス几知 見㭪遭（本誌第 46 年第 12 號二表七り）

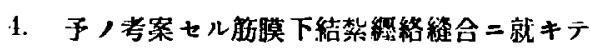

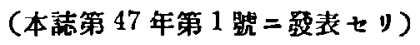

平井出正三君

主諭

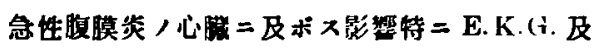

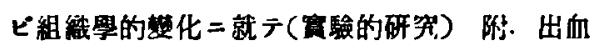

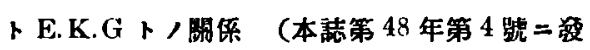
表セり)

考論文

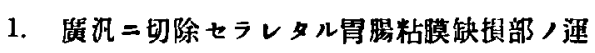

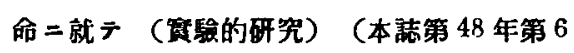
跳二覆セり)

2. 外傷性皮下腸管断裂二就キテ（追テ本誌二
破表 /

3. ジセドゥ氏病ニ於ヶル甲状腺切除街後儿心 睡死立ニ「ギネルゲン」ノ效果二就キテ（本詳

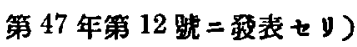

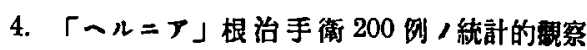

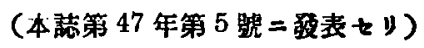

5. 股「ール 第 5 路二發表セり)

○田中文男君美學 雕山醫科大學教投田中文男 博士は昨年開催の同致授在職 25 年記念视賀會上 り睓呈の記念品代を以て君の講演を取緾め出版せ らろる筈にて毁に其の原稿す出來上り居りしが

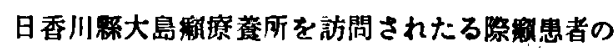
生活狀態を留て儌心に堪へざるを以て患者照安 として右金成干圆を同所に寄附せられたり

○日本文化講義 今般文部省は大學立直輁學校 に對し學生生徒に藏く人文の各方面より日本交化

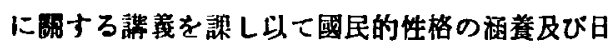

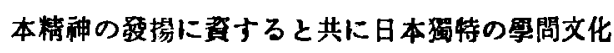
上閶ナろ十分なる理解體詔を得せしむる篇め楼威 ある學者等に委缺し日本文化满義を筫施せしむる こととなれるを以て岡山圈科大學に於ては次の通 り之を實施することとなり先つ第1回の偝演を本 月 28 日午後 1 時より開潇せり其の檴倣は

學業と人格學習院長 荒橫三郎先生 而して雨後の決定せる满師及び日時は㰠の如し 本年11月25 日午後 1 時より

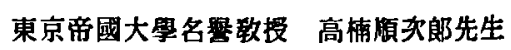
昭和 12 年 1 月 25 日午㖟 1 時上り 前獨道國大使 本多熊太郎先生

○周山醫學會第374回通常會

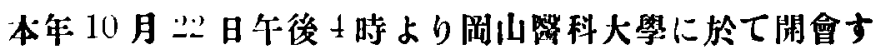

